\title{
Büyükdere Caddesinde Sanayileşme ve Sanayisizleşme Süreçlerinin Mekânsal Yansımaları (İstanbul-Türkiye)
}

\section{Spatial Reflections of Industrialization and Deindustrialization Processes in Büyükdere Street (Istanbul-Turkey)}

\author{
Uğurcan AYİK ${ }^{1}$ (D), Sedat AVCI ${ }^{2}$ (c)
}

${ }^{1}$ Gaziantep Üniversitesi, Fen-Edebiyat Fakültesi, Coğrafya Bölümü, Gaziantep, Türkiye

${ }^{2}$ İstanbul Üniversitesi, Edebiyat Fakültesi, Coğrafya Bölümü, İstanbul, Türkiye

ORCID: U.A. 0000-0003-2019-5151; S.A. 0000-0003-4371-5578

\section{öz}

Türkiye'de de sanayi tesislerinin kuruluş yerinin belirlenmesinde etkili olan faktörlerin ortaya konulması, sanayi coğrafyası ile ilgili çalışmalarda temel yaklaşımdır. Modern sanayiinin kuruluş şartları, sanayi tesisinin neden orada olduğunu açıklamak için kullanılan faktörlerden oluşmaktadır. Ancak zaman içinde tesisin orada kurulmasına neden olan unsurlar eski önemini yitirebilir. Bu durum yerel faktörlerin bir sonucu olabileceği gibi sermaye hareketlerine bağlı olarak da gerçekleşebilir. Özellikle arazi kullanımı açısından ele alındığında sanayi tesislerinin kuruluş yerinin belirlenmesinde planların da ayrı bir yeri vardır. Yapılan planlar sanayi tesislerinin kuruluşunu teşvik ettiği gibi, mevcut sanayi tesislerinin kapanmasına da yol açabilir. Bir tesisin kapanması sanayi alanlarında merkezden çevreye doğru bir yer değişiminin veya tesislerin farklı bir alanda yeniden kurulmaları ile ilgili süreçlerin sonucu olabileceği gibi sanayisizleşmeye de işaret edebilir. Genel ekonomi politikaları, siyasi ve ekonomik konjonktür, yerel planlama kararları gibi birçok faktör, sanayisizleşme sürecinde etkili olmaktadır. Çalışmaya konu olan Büyükdere Caddesi, yerel planlama kararları ile oluşturulan sanayi alanlarında zaman içinde ortaya çıkan fonksiyon değişimine işaret etmektedir. Çalışma alanında 1952-1978 döneminde yaşanan sanayileşme, 1990-2010 döneminde yerini sanayisizleşme sürecine bırakmıştır. Sanayisizleşme sürecinin yarattığı mekânsal değişikliğin temelinde; arsa fiyatının üretimden elde edilecek kârdan daha fazla olması ve bu kârın çok daha düşük bir risk ile sağlanması gibi faktörler yatmaktadır.

Anahtar kelimeler: Levent, Rant, Ekonomi Politikaları

\section{ABSTRACT}

Identifying factors affecting the location of industrial facilities is the main approach in studies related to industrial geography in Turkey. The founding conditions of modern industry are used to explain why a specific industrial plant stands at a specific location. However, over time, the factors that caused the facility to be installed there may lose its importance. This may be the result of local factors or capital movements. Particularly in terms of land use, plans have a special place in determining the location of industrial facilities. Plans can encourage the establishment of industrial plants, as well as the closure of existing industrial plants. The closure of a factory may be the result of decentralization, relocation, or deindustrialization. Many factors such as general economic policies, political and economic conjuncture, and local planning decisions affect the deindustrialization process. Büyükdere Street shows that the function of industrial areas are changed by local planning decisions. Industrialization activities in the period 1952-1978 were replaced by deindustrializationin the 1990-2010 period. On the basis of the spatial changes created by the deindustrialization process the price of land is higher than the profit from production.

Keywords: Levent, Rent, Economic Policies

Başvuru/Submitted: 25.11.2019 • Revizyon Talebi/Revision Requested: 13.05.2020 • Son Revizyon/Last Revision Received: 23.05 .2020 • Kabul/Accepted: 30.05 .2020 - Online Yayın/Published Online: 15.06 .2020

Sorumlu yazar/Corresponding author: Sedat AVCI / sedtavci@istanbul.edu.tr

Atıf/Citation: Ayik, U. \& Avci, S. (2020). Spatial reflections of industrialization and deindustrialization processes in Büyükdere Street (Istanbul-Turkey). Cografya Dergisi. Advance online publication. https://doi.org/10.26650/JGEOG2019-0054 


\section{EXTENDED ABSTRACT}

The location of industrial plants and the process of industrialization are the basic areas of interest for industrial geography. Identifying factors affecting the location of industrial facilities is the main approach in studies related to industrial geography in Turkey. The founding conditions of modern industry are used to explain why a specific industrial plant stands at a specific location. However, over time, the factors that caused the facility to be installed may lose its importance. These changes in significance may be the result of local factors or capital movements. A closed factory may be the result of decentralization, relocation, or deindustrialization. The international deindustrialization process is mostly dependent on capital movements.

The study is mainly based on field observations and evaluation of resources. In order to create the visual material for the study, available data was processed on aerial photographs and satellite images from different dates. The aim of this study was to reveal the changes that occurred while experiencing the industrialization and deindustrialization process of a field and to determine the factors that affected this change.

Büyükdere Street, which was the subject of the study, is an example of an industrial area created by local planning decisions. Some of the industrial facilities established before 1950 remained in the city, causing various problems. With the plan, an area on the edge of the city but not far from the city was deemed suitable for the establishment of industrial facilities. The main reason for this was the ownership and legal status of the area in question. Due to the fact that this area was located within village boundaries, the legal process for cities did not have to be implemented. Gültepe, which is located to the west of Büyükdere Street, had a large number of cheap laborers and was one of the factors that promoted the development of industry. As a result, various factories were established on Büyükdere Street from 1952 to 1978. Most of these factories belonged to the pharmaceutical industry. In addition, a wide range of manufacturing from electronic goods to bicycle and motorcycle tires were produced. Factories with a large number of workers also caused population growth in the immediate vicinity. As Gültepe developed further, new slum areas such as Çeliktepe and Sanayi Mahallesi emerged.

Over time, the factories remained in the city, as before 1950, and plans were made again to move them out of the city. The main problems arising after the industrialization process were; the transport of raw materials and finished goods, the crowds caused by the arrival and departure of workers, and the presence of factories within the settlement. The emergence of these problems in a short time period of 25-30 years was a clear indication that there were disruptions in planning and implementation.

The neoliberal policies implemented after 1980 also had significant spatial consequences in Istanbul. In the plans made during this period, new functions were given to the industrial part of Büyükdere Street. At first, it became an international business and financial center. After a while, the political power chose another place in Istanbul for the finance function and the trade function around Levent became even stronger. As a result, the industrialization process on Büyükdere Street was replaced by a deindustrialization process. Production of some of the existing factories were shifted to different locations and settlements, while others continued to operate until the completion of licenses and agreements, or have completely closed to produce in more profitable areas in other countries. This process was experienced intensively in the 1990-2010 period. On the basis of the spatial change created by the deindustrialization process the price of land was higher than the profit generated from production and this profit was provided at much lower risk.

The old industrial areas on Büyükdere Street (between $1^{\text {st }}$ Levent and $4^{\text {th }}$ Levent) now have the function of trade and housing. Shopping centers, offices, and residences have replaced old industrial facilities today. This also indicates a significant change in the city's skyline. In factory buildings, the height of the floors is relatively limited and dominated by more horizontal architecture. Today, there are multistory buildings in place. Nowadays, traffic congestion and crowds are caused by people coming to shopping centers or working in new workplaces. Industrial production has ended in this part of Büyükdere Street. The dominant function is mainly for consumption. In addition, the headquarters of various companies are located in this area. Use as a home is a function that has become widespread in recent years.

Urbanization leads to many differences in landscape. In the Büyükdere Street case, the industrialization process led to many changes while the deindustrialization process changed both function and landscape. 


\section{GİRIŞ}

Sanayi faaliyetleri, belli bir hammaddenin işlenerek, yarı mamul veya mamul hale getirilmesi sürecidir. $\mathrm{Bu}$ faaliyetler gerçekleştirilirken işgücü, enerji, sermaye, ulaşım ve pazar gibi doğrudan üretim ile ilişkisi açık unsurlar ile yasa koyucunun uyguladığı politikalar gibi doğrudan üretim ile ilişkili gibi görünmeyen, ancak üretimi denetleyen unsurlar etkili olmaktadır. Söz konusu üretim, ev ve atölye tipi sanayi faaliyetlerinin aksine daha geniş alan kaplayan, üretim değerleri miktar ve ederi bakımından daha hacimli olan fabrikalarda gerçekleștirilir. Sanayi tesisleri ve kullandıkları teknoloji yanında üretilen ürünler, işgücü ve verimlilik, pazar koşulları gibi değişik faktörlerle yakından ilgilidir. Sanayi faaliyetlerinin oluşum ve dağılışında etkili olan bu faktörler sabit değildir ve zaman içinde etkileri değişim gösterir. Ortaya çıkan bu değişim, üretim mekânlarının lokasyonu üzerinde de etki yaratır.

Sanayisizleşme, genel olarak tarımsal ve sanayi üretimi ile hizmetlerden meydana gelen gayri safi yurtiçi hasıla içindeki sanayinin payının azalması sürecine işaret eder. Süreç sonucunda ülke veya bölge ölçeğinde gayrisafi yurtiçi hasılayı oluşturan bileşenlerdeki değişim izlenebilir. Bu durum, sanayisizleşmenin ekonomik açıdan taşıdığı rolü göstermektedir. Ancak sanayisizleşme; sadece ekonomideki sanayinin payının üretim hacmi veya istihdamın azalması yönünde değil, aynı zamanda mekânsal kullanım üzerinde de etkili olmaktadır. Sanayisizleşme; sanayinin merkezden çevreye doğru yer değiştirmesi (decentralization), sanayi tesislerinin yer değiştirmesi (relocation) ve sanayi alanının başka bir fonksiyon kazandığı alanlar (deindustrialization) şeklinde gerçekleşir. Bu süreç, mekânsal kullanımda ortaya çıkan değişimlerle görünür hale gelmektedir. Zaman içinde şehir içinde kalmış eski üretim mekânlarının, yeni bir fonksiyon ile tekrar kullanıma açılması bu mekânsal etkiyi yansıtmaktadır. Sanayisizleşme, söz konusu alanlarda üretim faaliyetlerinin fiziki veya yasal nedenlerle sürdürülememesinin bir sonucu olabileceği gibi, artan arazi fiyatlarının oluşturduğu rant nedeniyle daha fazla gelir getirecek farklı kullanım şekillerinin tercih edilmesi şeklinde de gerçekleşebilmektedir (Ayik ve Avc1, 2018b, s. 506).

\section{AMAÇ VE YÖNTEM}

Çalışmanın temel amacı, sanayileşme ve sanayisizleşme süreçlerinin kısa bir zaman diliminde yaşandığı Büyükdere
Caddesi'nin 1. Levent ile 4. Levent arasindaki kesiminde gerçekleşen değişimin ortaya konulması ve bu değişimde etkili olan unsurların belirlenmesidir. Bu çalışma büyük ölçüde; 35-40 yıl gibi bir süreyi içeren zaman dilimindeki gözlemlere, sanayi kuruluşlarına ait kaynaklara, bu tesislerde çalıșan veya bölgede yaşayanların anlattıklarının değerlendirilmesine dayanmaktadır. Yeri geldiğinde ilgili literatürden, gayrimenkul değerleme raporlarından ve gazete haberlerinden de faydalanılmıştır. Görsel materyelin bir kısmı ise çeșitli hava fotoğrafı ve farklı tarihlerdeki uydu görüntülerinin işlenmesi ile oluşturulmuştur.

\section{SANAYIDE YER SEÇIMİ TEORILLERİ VE BÜYÜKDE- RE CADDESİ'NDE SANAYIIININ GELIŞSIMINDE ROL OYNAYAN FAKTÖRLER}

Sanayinin kuruluş yerinin belirlenmesinde etkili olan faktörlerin açıklanmasına yönelik teorilere ilişkin ilk örnekler 1826'da yayınlanan von Thünen'in arazi kullanım bedeli ile pazar arasındaki mesafeyi ele aldığı çalışması esas alınarak geliştirilmiş̧ir (Haggett, 1965, s. 161). Özellikle 20. yüzyılda çeşitli araştırıcılar, önceki çalışmaları göz önünde bulundurarak sanayiinin kuruluş yeri ile ilgili teoriyi, adeta göle atılan bir taşın yarattığı dalgalar gibi, her adımda daha kapsamlı hale getirmiştir.

Ekonomik coğrafyanın kurucularından biri olarak kabul edilen Alfred Weber, ilk kez 1882 yllında W. Launhardt'1n “Die Bestimmung des zweckmassigsten Standorts einer gewerblichen Anlage" başlıklı yazısında ileri sürülen düşünceleri de geliştirerek (Lösch, 1978, s. 18), sanayinin kuruluş yeri ile ilgili teoriyi oluşturmuştur. 1909 yılında Almanca yayınladı̆̆ı "Über den Standort der Industrien" isimli kitabında yer alan teorinin bilinirliği, kitabın 1929 yılında "Theory of the Location of Industries" başlığı ile İngilizce yayınlanmasından sonra (Weber, 1929) daha da artmıștır. Weber'in teorisine göre sanayi tesisleri, hammadde ve pazara ulaşım maliyetlerinin en düşük olduğu yerde kurulmalıdır.

Sanayiinin kuruluş yeri ile ilgili teorilerin etkileri günümüz ekonomik coğrafya çalışmalarında üç farklı şekilde ele alınmaktadır (Aoyama, Murphy ve Hanson, 2011, s. 81-83). Bunlardan ilki "coğrafi iktisat" başlığı altında ele alınabilir. Krugman, ticaret ve konum teorilerini birleştirerek ekonomiye yeni bir bakış açısı kazandırmıştır¹. Yapılan çalışmalar, ölçek

1 Krugman, 1991'de yayınlanan makalesinde, bir ülkede sanayileşmiş bir merkez ile tarımsal faaliyetlerin hakim olduğu bir çevrenin nasıl meydana geldiğini anlamaya yönelik basit model geliştirdiğini vurgulamaktadır. Modele göre, birim maliyetin düşmesi ve maliyet avantajının oluşması olarak tanımlanan ölçek ekonomisinin (Krugman, 1980, s. 950) gerçekleșebilmesi için tașımacılık maliyetlerinin en aza indirmek isteyen firmalar, ürünlerin dağıtımını da göz önünde bulundurarak merkezde bulunmayı daha fazla talep etmektedirler. Merkez çevresindeki dağılış kalıbının oluşması ise; ulaşım maliyetlerine, ölçek ekonomisi koşullarının sağlanmasına ve üretimin milli gelir içindeki payına bağlıdır (Krugman, 1991, s. 483). 
ekonomisinin, ticaretteki dağılış kalıbının nasıl oluştuğunu açıklaması bakımından da önemlidir. İkinci görüş Frank (1967) ve Wallerstein (1979) tarafindan ortaya konulan "yapısal gelişme teorisi"ne dayanan modeldir. Bu modelde 1970'li y1llarda İngiltere ve ABD'de yaşanan ekonomik krizi aşabilmek için ekonomi politiklarında yapılan değişikliklerin sonuçlarının belirlenmesi hedeflenmiştir. Ancak bu teorinin bölgesel gelişme ve gerilemeyi anlamaya olan katkısı, eski sanayinin kuruluş yeri teorilerinden çok farklıdır ve büyük ölçüde "nedensel iktidar ilişkilerini" esas almaktadır. Ekonomik coğrafya alanında yapılan çalışmalarda, konunun diğer paydaşlarını oluşturan iş ve yönetimden araştırmacılar ile birlikte; uluslararası iş teorileri, kurumsal ekonomi, uluslararası ölçekte doğrudan yatırımların yöneldiği alanlar ile çok uluslu işletmelerin konumlarının araştırılması, günümüzdeki üçüncü görüşü oluşturmaktadır.

$\mathrm{Bu}$ değerlendirmeler hangi yaklaşımla ele alınırsa alınsın, sanayinin kuruluş yerinin belirlenmesinde birçok faktörün etkili olduğunu göstermektedir. Ancak bu faktörler sabit değildir. Örnek olarak kuruluş yerinin belirlenmesinde bir etken olarak işgücü, uzun yıllar sadece miktar ve ödenen ücret bakımından değerlendirilmiştir. Günümüzde işgücünün niteliği de önemli hale gelmiştir. Bunun sonucunda birçok işletme, ucuz ve bol emeğin bulunduğu yerleri değil, üretim için nitelikli işgücünün bulunduğu alanları tercih etmeye başlamıştır. Eskiden gündemde olmayan ancak iklim özellikleri, kültür, eğlence gibi farklı olanakların sunulduğu alanların varlığ gibi beklentilere sahip yeni nesil nitelikli işgücü, sanayi tesislerinin kuruluş yerinin belirlenmesinde farklı değerlendirmeleri de zorunlu hale getirmektedir. Ayrıca faaliyetler arasında koordinasyonun daha kolay sağlanabildiği sistemlerin gelişmesi ve teknolojik ilerlemeler mesafenin önemini azaltmakta; inovasyona dayalı üretim faaliyetleri, özellikle üniversitelere ve araştırma laboratuvarlarına yakın alanlara diğer yerlere nazaran daha fazla avantaj sağlamaktadır (Aoyama, Murphy ve Hanson, 2011, s. 83-84).

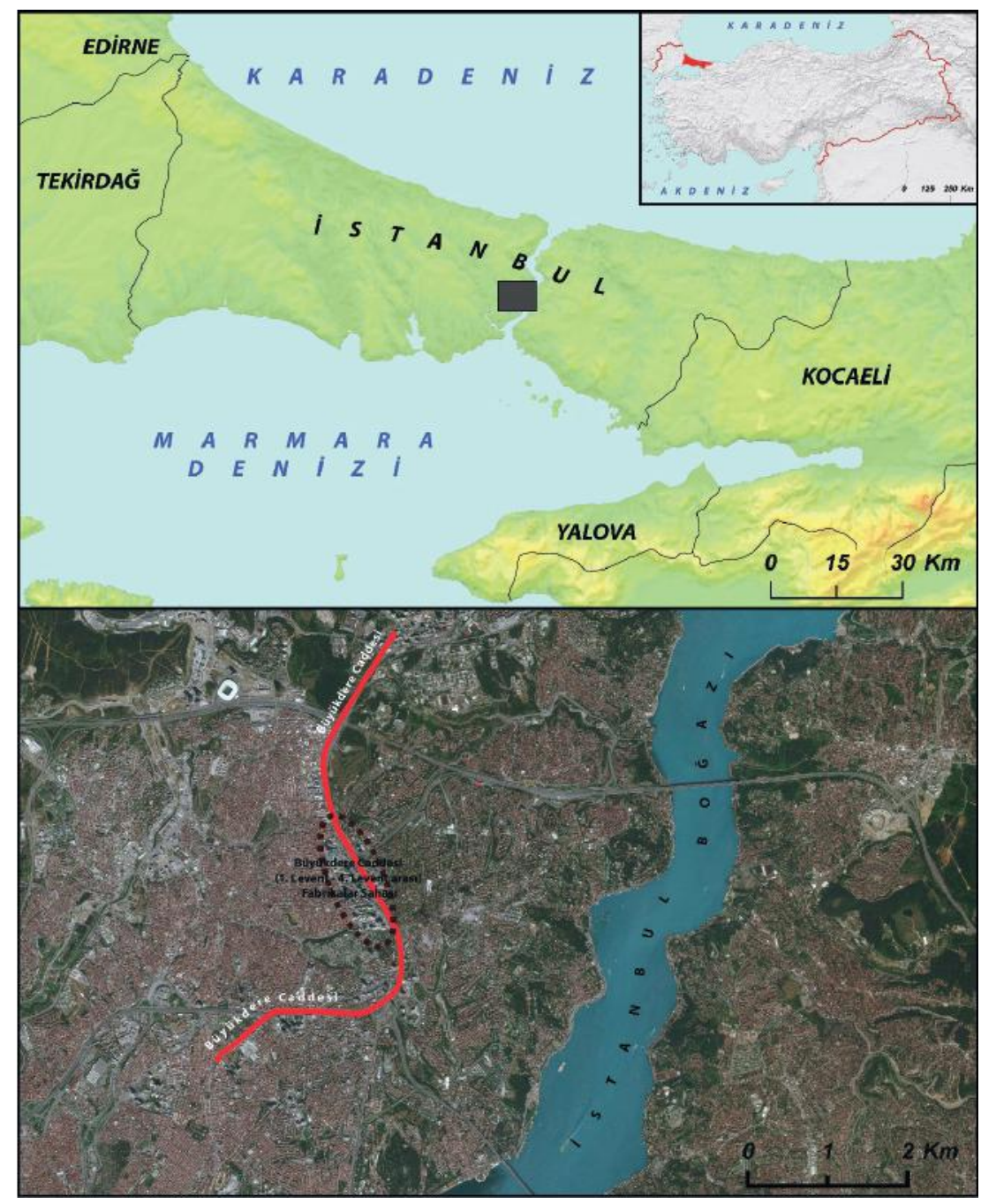

Şekil 1: Büyükdere caddesinin (1. Levent-4. Levent arası) yeri.

Figure 1: Location of Büyükdere Street (between $1^{\text {st }}$ Levent- $4^{\text {th }}$ Levent). 
Sanayinin kuruluş yeri ile ilgili tüm yaklaşımlarda; yer, ürün ve üretimile ilgiliunsurların daha iyi anlaşılması hedeflenmektedir. Yer seçiminde "neden burası" sorusu, çoğu zaman yer, ürün veya üretim faktörlerinden hangisinin farklılığa neden olduğunun değerlendirilmesiyle cevaplanmaya çalışılmaktadır. Kullanılan modeller kuruluş yerinin geneli için anlamlı sonuçlar üretebilmektedir. Başka kelimelerle modeller daha çok bu fabrikaların neden İstanbul'da kurulduğunu açıklamak için yeterlidir. Buna karşl1ık ölçek büyüdüğünde, genellemelerin dışına çıkılması gerekmekte, çoğu zaman özel koşullar söz konusu olmaktadır. Bu durum, Büyükdere Caddesi'nin 1. Levent ile 4. Levent arasındaki kesimi için de geçerlidir.

İstanbul bulunduğu konum ve idari, sanayi, ticaret, eğitim, kültür gibi fonksiyonları itibariyle sürekli bir çekim merkezi olmuştur. Bu durum, nüfusun hızla artmasına ve alansal olarak da büyümesine yol açmıştır. Büyümenin etkisi ile kısa zaman dilimlerinde mevcut fonksiyonların değiştiği görülmektedir. Büyükdere Caddesi (özellikle 1. Levent ile 4. Levent arası), İstanbul'da kısa sürelerde fonksiyon değişiminin ortaya çıktığı yerlerden birisidir (Şekil 1).

Büyükdere Caddesi olarak tanımlanan yolun gelişimi, Boğaziçi'nin yerleşim tarihi ile yakından ilişkilidir. Bizans Dönemi'nde Boğaziçi'nde bağcılık, bahçecilik ve balıkçılık faaliyetlerinin sürdürüldüğü kırsal yerleşmeler yer alıyordu. $\mathrm{Bu}$ yerleşmeler daha çok kıyıya paralel uzanan, ancak vadiler boyunca iç kısımlara genişleyebilen yerlerde idi ve ulaşım çoğunlukla denizden sağlanıyordu. Yerleşme düzeni Osmanlı Devleti zamanında da bu özelliğini ana hatlarıyla korumuştur. Özellikle 18. yüzyılın başından itibaren Osmanlı'nın sosyal düzeni, kişi ve grupların devlet ile ilişkisini de esas alarak mekâna yansımıştır. Boğaziçi'nin Rumeli yakasında saray ve yakın çevresi ile idarecilerin yaptırttığı yalı ve hasbahçeler, daha kuzeyde ise yüksek gelir düzeyine sahip sarraf, tüccar gibi ticaret erbabı ile çeşitli ülkelerin yazlık sefarethaneleri yer alıyordu (Artan, 1994, s. 282-283). Ulaşım daha çok denizyolu veya kıyı boyunca uzanan sahil yolu kullanılarak sağlanıyordu. Bununla birlikte özellikle İstanbul Boğazı'nın kuzeyinde bulunan yerleşmelere, plato düzlüğü üzerindeki bir yol ile ulaşıldığg da bilinmektedir. Bu yol, Belgrad ormanında 1620-1839 y1lları arasında İstanbul'un su ihtiyacını karşılamak üzere yapılan ve zaman içinde mesire yeri olma fonksiyonu kazanan bentlere ulaşmak için de kullanılıyordu (Görcelioğlu, 1985, s. 46 vd). Belli kesimleri zaman içinde iyileştirilen ve genişletilen bu yol, Büyükdere Caddesi'nin de ilk halini meydana getirmektedir.

İstanbul'un gelişmesi ve güzelleştirilmesi için her dönemde çeşitli girişimlerde bulunulmuştur. İlk çalışmaların 1836-1837 yıllarında Alman generali von Moltke'nin yaptığı çizimler üzerinde gerçekleştirildiği düşünülmektedir. İstanbul'un çeşitli unsurları daha sonraki yıllarda planlanmaya çalışılmış, 1930'1 yıllardan itibaren Prost tarafından kapsamlı planlar hazırlanmıştır (Tapan, 1998, s. 75 vd). İstanbul'un modern bir şehir görümüne kavuşturulması ve konut ihtiyacının karşılanması, 1950'li yılların başından itibaren İstanbul' da yaşanan imar hareketlerinin nedenleri arasındadır (Aysu, 1994, s. 362-363). Bu tarihlerde sanayileşmenin de yoğun olarak yaşanmaya başlaması, sorunun büyümeden çözümü için çabaları da gündeme getirmiştir. Tümertekin, "İstanbul'un kimliğini oluşturan bir başka özellik olan denetimsizlik, sorunların çoğalmasına ve kalıcı olmasına yol açmıştır; dolayısıyla da sorunların çözümü üzerinde erken teşhisin değil, tedavinin etkili olacağı ortaya çıkmaktadır" demektedir (Tümertekin, 1997, s. 29-30). Bu planlama çalışmalarının mekânın şekillenmesindeki etkisinin sınırlılığına dikkat çekmesi açısından önemlidir. Bununla beraber genel bir plan olmamasına karşıllık çeşitli projeler ile belli alanların geliştirilmesi ve düzenlenmesi için çalışmalar yapılmıştır.

İstanbul'un Avrupa Yakası'nda, farklıyerlerde gerçekleştirilen imar çalışmaları arasında, Emlak Kredi Bankası tarafından gerçekleştirilen Levent'teki konut projesi de yer alır. Proje, eski bir çiftlik arazisinin iskâna açılması ${ }^{2}$ ile oluşturulmuştur (Tümertekin, 1997, s. 230; Aysu, 2006, s. 107; Erbaş, 2012, s. 5). 1868 tarihli Dersaadet İdare-i Belediye Nizamnamesi ile oluşturulan Beşiktaş'ın içinde yer aldığı 7. Daire'ye bağlı bu

2 Fransız Hükümeti tarafindan görevlendirilerek Osmanlı Devleti topraklarında incelemelerde bulunan Dr. Antonie Olivier, $1792-1798$ yılları arasında İstanbul çevresinde seyahatlerini gerçekleştirmiştir. Onun seyahatnamesinde verdiği bilgilere göre Beşiktaş sirtlarında yer alan ve günümüzde Büyükdere Caddesi’nin doğusunda bulunan bölge, 18. Yüzyılın son çeyreğinde I. Abdülhamit (padişahlığı 1774-1789) zamanında, Kaptan-1 Derya Cezayirli Hasan Paşa'ya gelir sağlaması amacıyla verilmiștir. Cezayirli Hasan Paşa kendine verilen araziye bahçeler ve binalar yaptırmıș, aynı zamanda burayı korumak üzere denizci askerlerden oluşan bir bölüğ̈̈, muhafız olarak buraya yerleştirmiştir. Denizci askerlerin levend olarak isimlendirilmesi nedeniyle burası "Levend Çiftliği" adıyla anılmaya başlanmıştır. III. Selim tarafından kurulan Nizam-ı Cedid ordusuna ait kışlalardan biri Levend Çiftliği’nde yer alıyordu. Çiftlik sınırları içinde tüfenk ve kasatura yapılan bir imalathane de vardı. Buradaki tesiste üretim zaman zaman kesintiye uğrasa da uzun y1llar devam etmiştir. Farklı özelliklere sahip birliklerden oluşan çiftlikte, yaklaşık 5200 asker bulunuyordu (Olivier, 2016, s. 84-85). Çiftliğin askeri fonksiyonun zaman içinde ortadan kalktığı ve Cumhuriyet dönemine bu alanın tarımsal faaliyetlerin gerçekleştirildiği bir yer olarak ulaştığı bilinmektedir. II. Dünya Savaşı sonrasında beliren konut sıkıntısının giderilmesi amacıyla çeşitli konut projeleri geliştirilmiştir. Bu projelerden biri de Levent projesidir. 1947 yılında çiftlik arazisi üzerinde Emlak Kredi Bankası’nın toplu konutları planlanmış, 1950-1960 yılları arasında kademeli olarak farklı özellikteki villa ve apartmanlardan oluşan 1.-4. Levent projeleri gerçekleştirilmiştir (Baydar, 1998, s. 47-49). 


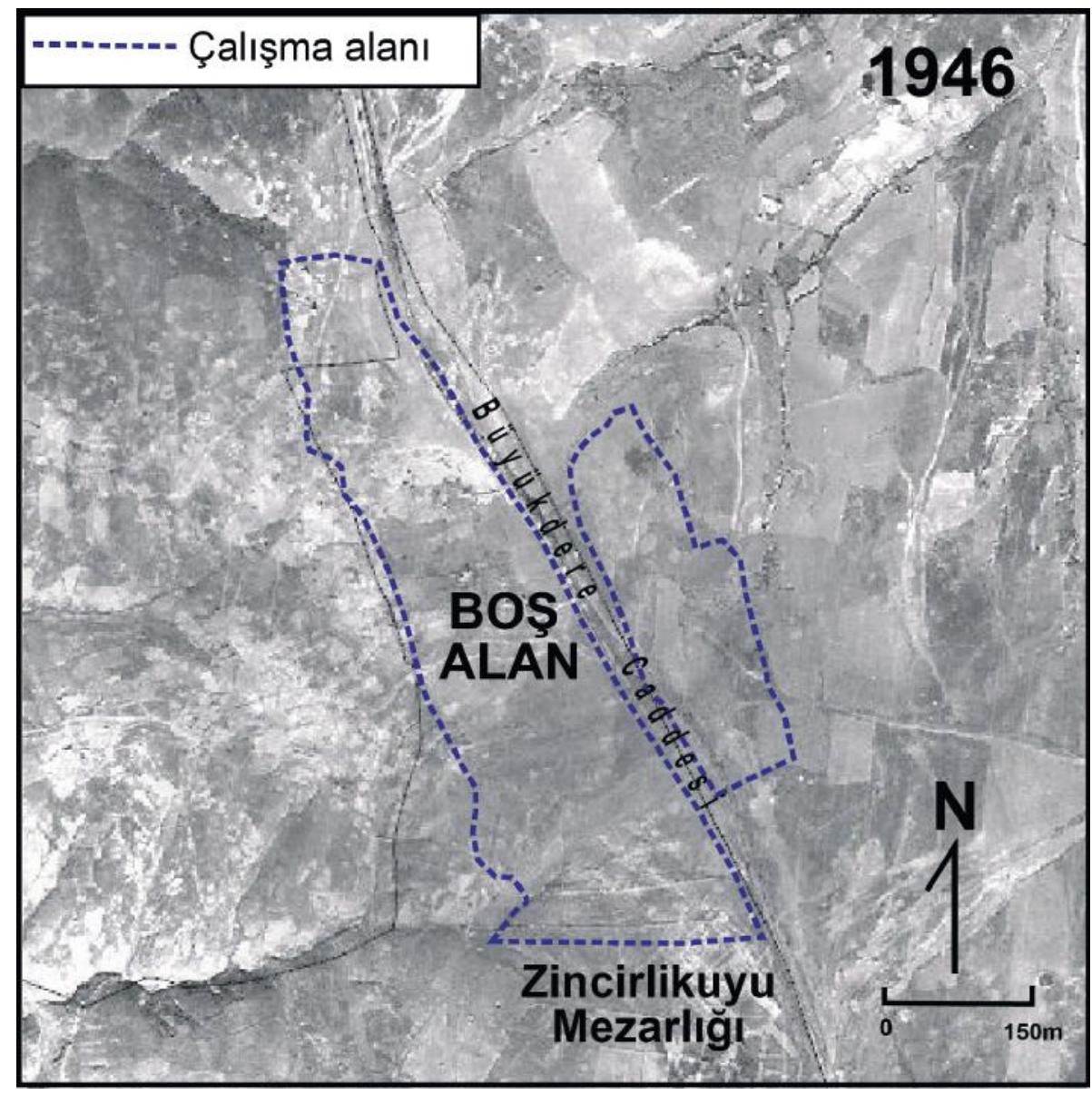

Şekil 2: Büyükdere caddesi (1. Levent-4. Levent arası) ve çevresinin 1946 yılına ait hava fotoğrafı (https://sehirharitasi.ibb.gov.tr/). Figure 2: Aerial photo of Büyükdere street (between $1^{\text {st }}$ Levent- $4^{\text {th }}$ Levent) and its surroundings from 1946.

sahanın sınırları ${ }^{3}$, idari bakımdan daha sonraki dönemlerde bazı değişiklikler göstermiştir (Akbayar, 1998, s. 4-5). Büyükdere Caddesi'nin batısı 1954 yılına kadar Beyoğlu İlçesi’ne, bu tarihten sonra ise Şişli İlçesi’ne bağlı Kâğıthane köyünün sınırları içinde yer alıyordu. Bu durum 1987 yılında Kâğıthane ilçesinin kurulmasına kadar devam etmiştir (Kâğıthane, 2008, s. 17-18). Büyükdere Caddesinin doğusu ise Beşiktaş ilçesinin Levent Mahallesi'nden oluşmaktadır. İstanbul'da sanayiinin dağılışı, zaman içinde bazen kendiliğinden, bazen yapılan yasal düzenlemelerle şekillenmiştir. 1930 yılında yürürlüğe giren Hıfzısıhha Kanunu ile sanayinin dağılışının denetlenmeye başlaması, 1937'de Prost'un hazırladığı Nazım İmâr Planı'nda belli alanların sanayi bölgesi olarak tanımlanması, İstanbul'da sanayinin dağılışının önemli aşamalarını oluşturmaktadır. 1952 yılında Imar Müşavirleri Heyeti tarafından İstanbul'un sanayi bölgelerinin ortaya konulmasına ilişkin çalışmalara başlanmış, geniş katılımlı bir komisyon tarafından İstanbul'un sanayi bölgeleri oluşturulmuştur. Ancak imzalanma aşamasında çıkan sorunlar nedeniyle İmar Müşavirlik Heyeti’nin bu raporu, kendi imzasıyla Belediye Meclisi'ne sunduğu ve 1955 yılında bazı değişikliklerle İstanbul Belediye Meclisi'nce onaylandığg bilinmektedir. Bu plana göre Mecidiyeköy ile Levent arasındaki kesim tanımlanan sanayi bölgeleri arasında yer alıyordu (Tümertekin, 1972, s. 7-8). Levent çevresinin sanayi tesislerine ev sahipliği yapmasında, bu alanın idari statüsü de etkili olmuştur. Tümertekin'in de özellikle vurguladığı gibi; şehre bitişik, şehrin imkânlarından faydalanılan, ancak idari bakımdan köy statüsü taşıyan veya ayrı belediye ile yönetilen alanlar sanayi tesislerinin yer seçiminde önde gelen yerleri oluşturmaktadır (Tümertekin, 1970, s. 61). Bu tespit 1950'li yıllarda Kâğıthane köyü sınırları içinde kalan Büyükdere Caddesi'nin batısının, neden sanayi tesisleri için kuruluş yeri olarak tercih edildiğini de açıklamaktadır. Şehir içinde yer alan ancak ticari, ekonomik veya yasal zorunluluklar nedeniyle şehir dışına çıkması gereken sanayi tesisleri ile yeni kurulacak tesisler için bu alan tercih edilmiş ve çeşitli fabrikalar yapılmıştır.

3 Bu alanın sınırları deniz kıyısında Dolmabahçe ile Kayalar (günümüzde Aşiyan mezarlığı) arasında, iç kesimde ise Levend Çiftliği ve Şişli Feriköy’e kadar olan alandaki köyleri içine alıyordu. 
Tablo 1: Büyükdere Caddesinde (1. Levent-4. Levent arası) yeralan sanayi tesislerinin faaliyete geçiş ve kapanış tarihleri.

Table 1: Starting and closing dates of industrial facilities located on Büyükdere Street (between $1^{\text {st }}$ Levent and $4^{\text {th }}$ Levent).

\begin{tabular}{|c|c|c|c|}
\hline \multicolumn{3}{|c|}{ Fabrikanın } & \multirow[t]{2}{*}{ Yeni Fonksiyon } \\
\hline Faaliyete Geçiş Tarihi & Adı & Kapanış & \\
\hline 1952 & Eczacıbaşı Illaç Fabrikası & 2002 & Kanyon AVM (2006) \\
\hline 1954 & E.R. Squibb \& Sons Illaç Fabrikası & 1980'ler & Dini yapı alanı* \\
\hline 1956 & Philips Televizyon Fabrikası & 1990 & Metrocity AVM (2003) \\
\hline 1959 & Sandoz İlaç Fabrikası & 2005 & Finansbank Kristal Kule (2014) \\
\hline 1959 & Doğan Lastik Fabrikası & $1995-2000$ & Şekerbank Kule (2014) \\
\hline 1963-1964 & Neyir Triko & 1974 & Banka şubesi \\
\hline 1964 & Tekfen Ampul Fabrikası & 1998 & Tekfen Tower (2002) \\
\hline 1955 & Metal Kapak & 2010 yılında fabrika binası mevcut & Park Dedeman Otel (2015) \\
\hline 1969 & Apa Ofset Matbaası & 2000 başları & Apa Giz Tower (2008) \\
\hline 1970 & Fako İlaç Fabrikası & 2011 & İstanbul Tower 205 (Bina tamamlandı) \\
\hline 1971 & Roche İlaç Fabrikası & 2005 & Özdilek AVM (2014) \\
\hline 1974 & Deva İlaç Fabrikası & 2008 & Levent 199 Plaza (2014) \\
\hline 1978 & Esan Akü Fabrikası & 1999 & Otopark (1999) \\
\hline
\end{tabular}

*2016 yılında yapılan İmar Planı değişikliği ile bu alan, "dini yapı alanı” olarak tanımlanmış, Şubat 2020'de cami inşaatına başlanmıştır.

\section{BÜYÜKDERE CADDESI'NIIN (I. LEVENT - SANAYİ MAHALLELERI ARASI) SANAYILEŞME VE SANAYİSIZLESME SÜRECI}

Büyükdere Caddesi'nin I. Levent ile IV. Levent arasında kalan kesimi, aynı zamanda İstanbul'da arazi kullanımında kısa sürede meydana gelen değişikliklerin kolaylıkla izlenebildiği yerlerden birisini oluşturmaktadır. Seçilen alan, günümüzde Şişli ilçesinin Esentepe Mahallesi ile Beşiktaş ilçesinin Levent Mahallesi'nin bir kısmını içine almakta ve iki mahalle arasındaki sınır ise Büyükdere Caddesi'nden geçmektedir. 1946 yılına ait hava fotoğrafında söz konusu alanın boş araziden oluştuğu görülmektedir (Şekil 2). Sahanın hemen güneyinde Zincirlikuyu Mezarlığı yer almaktadır ${ }^{4}$.

Büyükdere Caddesi'nin sanayi için bir çekim merkezi haline gelmesi, başta ilaç sanayi olmak üzere farklı sanayi kollarındaki tesislerin bu alanı kuruluş yeri olarak seçmesine neden olmuştur. 1952-1978 yılları arasında Büyükdere Caddesi'nin yaklaşık 1-1,5 km'lik kısmında 13 sanayi tesisi kurulmuştur (Tablo 1). $\mathrm{Bu}$ alanın bir diğer özelliği de tesislerin geniş arsalara sahip olmalarıdır. Söz konusu fabrikalardan 4'ünün arazi büyüklügü 1-2 bin $\mathrm{m}^{2}$ arasında değişmektedir. 1 fabrika alanı 9 bin $\mathrm{m}^{2}$ ye yakın, 6 fabrikanın arazileri ise $10-15$ bin $\mathrm{m}^{2}$ arasında değişmektedir. En geniş alana sahip fabrikalar Eczacıbaşı İlaç Fabrikası ile Roche İlaç Fabrikası'dır. Her iki fabrikanın arazisi de 20 bin m²'nin üzerindedir (Ayik, 2018, s. 203-204).

1960 öncesinde faaliyete geçen fabrika sayısı 6'dır. Bu fabrikalardan Eczacıbaşı İlaç Fabrikası 1952 yılında, E.R.
Squibb \& Sons İlaç Fabrikası 1954, Metal Kapak Fabrikası 1955 yılında, Türk Philips 1956 yılında üretime başlarken 1959 yılında Sandoz İlaç Fabrikası ile Doğan Lastik Fabrikası onlara katılmıştır. Burada yer alan ilaç fabrikaları daha sonraki yıllarda eklenenler ile birlikte Türkiye ilaç sanayiinin önemli bir kısmını da oluşturmuştur. 1966 yılında onaylanan 1/5000 ölçekli İstanbul'un Sanayi Sahaları İmar Planı her geçen gün daha da büyüyen sanayi fonksiyonunun plana işlenmesi olarak da kabul edilebilir. $\mathrm{Bu}$ işlenme yeni sanayi tesislerinin de bu alanda kurulmasını sağlamıştır. Sanayiin bu alanı tercih etmesinin nedenleri arasında şehrin hemen bitişiğinde zamanın koşullarına göre uygun fiyatlı geniş arazilerin olması (Fotoğraf 1) ve yakınında Gültepe, Çeliktepe gibi gecekondu alanlarının gelişmeye başlaması ile bol işgücü kaynağına sahip olması gelmektedir.

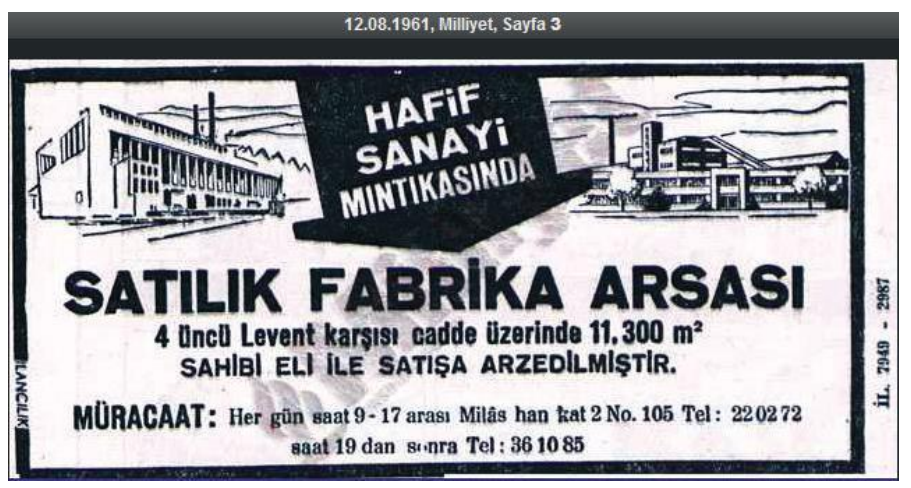

Fotoğraf 1: Levent'te bir fabrika arsasının 12.08.1961 tarihli Milliyet Gazetesindeki satış ilanı.

Photo 1: Sales announcement of a factory land in Levent in Milliyet Newspaper dated 12.08.1961.

4 Şehir içinde yer alan bazı mezarlık olarak kullanılan alanların yetersizliğine bağlı olarak 1935 yılında oluşturulmaya başlanan Zincirlikuyu mezarlığına ilk defin işlemi 1937 yılında gerçekleştirilmiştir (İşli, 1991, s. 503). Mezarın bir kısmı 1973 yılında yol yapımı sırasında istimlak edilmiştir. 
Bomonti sanayi bölgesinden ayrilan Neyir Triko (19631964), Tekfen Ampul Fabrikası (1964), Metal Kapak (1955) ve Apa Ofset (1969) 1970 yılına kadar bölgeye gelen diğer büyük sanayi kuruluşlarıdır. 1970'li yılların ilk yarısında ise bu bölgede 3 ilaç fabrikası (1970'de Fako İlaçları, 1971'de Roche Müstahzarları A.Ş., 1974'de Deva İlaç) daha kurulmuştur. Günümüzde Sapphire binasının yanında kalan ve otopark olarak kullanılan alanda ise 1978 yılında faaliyete geçen Esan Akü Fabrikası yer almıştır (Şekil 3; Fotoğraf 2).

İstanbul'da mekânsal değişim farklı zaman dilimlerinde hızlı bir şekilde gerçekleşmektedir. Bu nedenle hazırlanan planların çoğu için yasal süreç tamamlandığında, mevcut koşullar değişmektedir. Bu değişim mekânın kullanımındaki farklılaşma ile ilişkili olabildiği gibi, belirlenen fonksiyonların zaman içinde önemini yitirmesi veya yeni fonksiyonların kazandırılmak istenmesiyle de ilişkili olabilir. 1955 yılında hazırlanan 1/10.000 ölçekli Sanayi Bölgeleri Planı’nda, şehrin kenarında yer alması nedeniyle Mecidiyeköy ile Levent arasında kalan kesim sanayi alanı olarak belirlendiyse de, kısa sürede bu alanın yetersiz olacağı ortaya çıkmıştır. Bunun sonucunda 1966 tarihli sanayi alanları planında Levent çevresi yanında Maslak ve Ayazağa köyü de sanayi bölgeleri içine alınmıştır (Tümertekin, 1972, s. 8-9). Ancak mekânsal olarak ortaya çıkan koşullar (yeni fabrika alanlarının geliştirilememesi, fabrikaların konut alanlarının içinde kalması gibi) sanayiyi olumsuz yönde etkilerken, 1980’li yıllardan sonra uygulanan ekonomi politikaları Levent çevresindeki mevcut tesisleri yeni koşullara uymaya zorlamıştır.

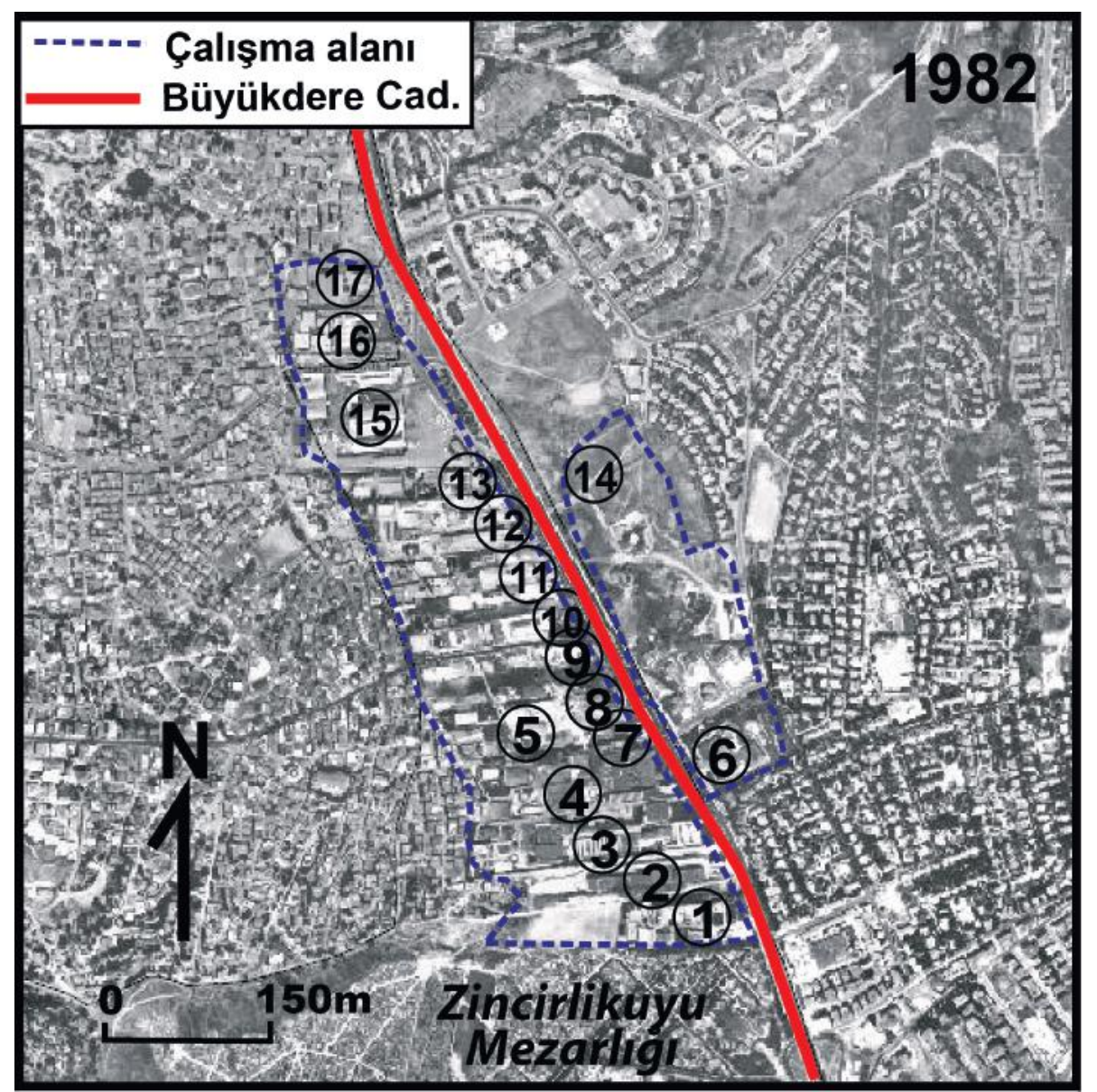

Şekil 3: Sanayisizleşme öncesinde Büyükdere Caddesi'nde (1. Levent-4. Levent arası) sanayi tesislerinin yerleşimi ve çeşitli kullanımlar [1-Türk Philips Sanayi (radyo ve televizyon fabrikası), 2-Renault-Mais, 3-Roche İlaç Fabrikası, 4-Eczacıbaşı Illaç Fabrikası, 5-Çeşitli küçük fabrikalar, 6-E.R. Squibb \& Sons Illaç Fabrikası, 7-Metal Kapak, 8-Apa Ofset Tesisleri, 9-Neyir Triko, 10-Deva İlaç Fabrikası, 11-Fako Illaç Fabrikası, 12-Tekfen Ampul Fabrikası, 13-Sandoz (Novartis) İlaç Fabrikası, 14-Boş alan, 15-IETT Levent Otobüs Garajı, 16-Doğan Lastik Fabrikası, 17-Esan Akü Fabrikası]. Figure 3: Pre-deindustrialization, settlement of industrial facilities and various uses in Büyükdere Street (between $1^{\text {st }}$ Levent-4 ${ }^{\text {th }}$ Levent) [1-Türk Philips Sanayi (electronic factory), 2-Renault-Mais (service and marketing), 3-Roche Ilaç Fabrikası (pharmacy), 4-Eczacıbaşı Ilaç Fabrikası (pharmacy), 5-small factory, 6-E.R. Squibb \& Sons Ilaç Fabrikası (pharmacy), 7-Metal Kapak (metal goods), 8-Apa Ofset Tesisleri (printing), 9-Neyir Triko (textile), 10-Deva ilaç Fabrikası (pharmacy), 11-Fako Ilaç Fabrikası (pharmacy), 12-Tekfen Ampul Fabrikası (manufacture of ampoule), 13-Sandoz (Novartis) Illaç Fabrikası (pharmacy), 14-Empty, 15-iETT Levent Otobüs Garajı (bus garage), 16-Doğan Lastik Fabrikası (tire factory), 17-Esan Akü Fabrikası (battery factory)]. 


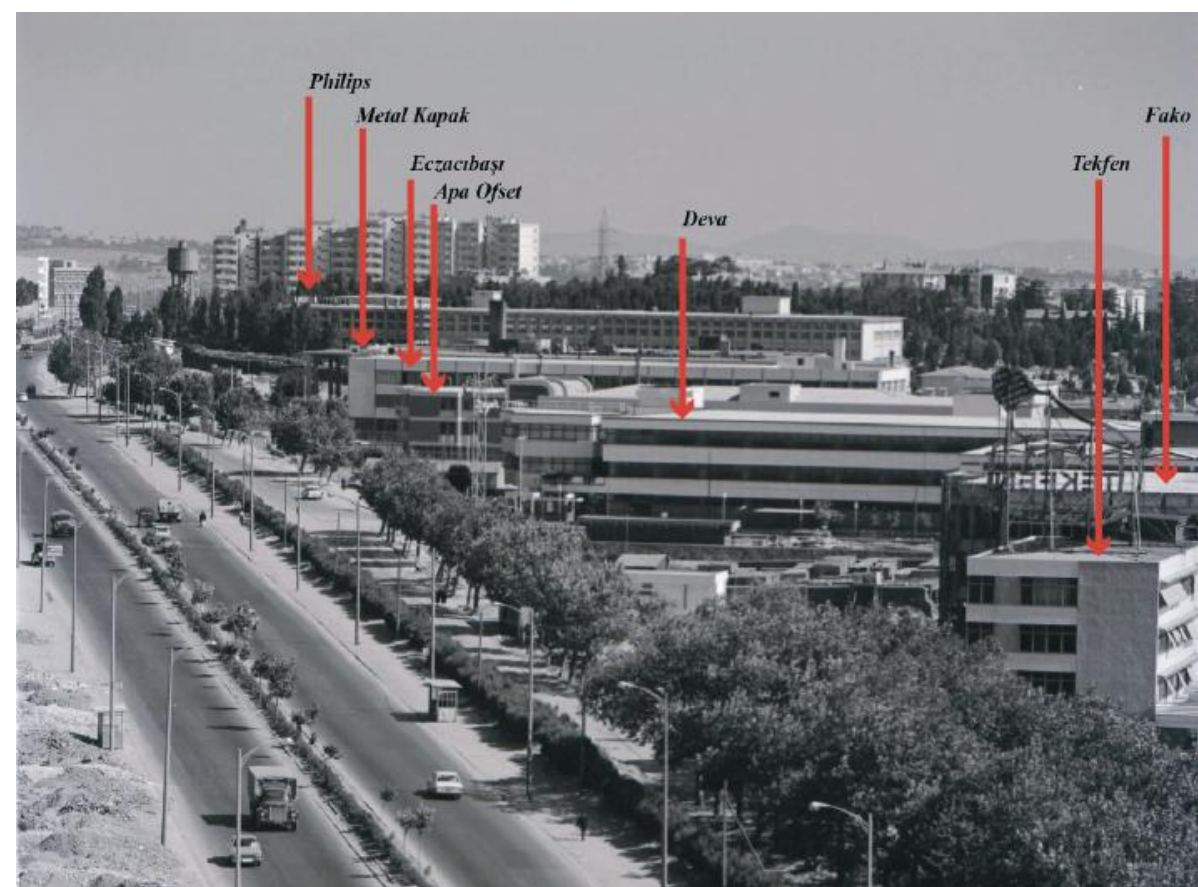

Fotoğraf 2: Büyükdere caddesinde (1. Levent-4. Levent arası) fabrikalar (1980'lerin sonu)(https://www.eczacibasiilac.com.tr/). Photo 2: Factories on Büyükdere Street (between $1^{\text {st }}$ Levent and $4^{\text {th }}$ Levent)(end of 1980's).

24 Ocak 1980 tarihli ekonomik istikrar tedbirlerinin zamanın koşullarının da katkısıyla ekonomi politikasına dönüşmesi sonucunda neoliberal politikalar zaman içinde hâkimiyet kazanmıştır. Neoliberal politikalar, esas olarak özel mülkiyet haklarının, serbest ticaretin kurumsallaşmasıyla belirginleşen ve bireysel girişimciliğe özgürlük sağlayarak ilerlemenin gerçekleşebileceğini vurgulamaktadır (Harvey, 2007, s. 2). Uygulanan politikaların mekânın kullanımı üzerinde de etkileri görülmüş, planlama alanları dışında kalan yerlerde veya planlı sahalarda yeni kullanımlar ortaya çıkmış, zaman içinde bu kullanımlar yasal mevzuata uygun hale getirilmiştir. Bu değişiklikler büyük kazançlara da aracı olmaktadır (Avcı, 2014, s. 323-324). 1980'li yılların başından itibaren İstanbul için "küresel kent" tanımı yapılmaya başlamıştır. İstanbul'un küresel kent kimliği ile tanımlanmaya başlaması dünya genelinde olduğu gibi Türkiye'de de ekonomik, sosyal, politik ve mekânsal alanlardaki dönüşümlere işaret etmekte ve dönüşüm için üretilecek politikalara da öneriler sunmaktadır. $\mathrm{Bu}$ öneriler, merkezi yönetimler yanında yerel yönetimlerin de İstanbul'un küresel kent yapılması adına projeler üretmelerine neden olmuştur (Öktem, 2016, s. 39 vd). Bu kapsamda 1980'li yılların ikinci yarısından itibaren Levent ve çevresi için "uluslararası iş ve finans merkezi olma" fonksiyonu belirlenmiştir. Merkez Bankası, Unkapanı ve Karaköy'de ki şubelerinin içinde yer alacağı Merkez Bankası İstanbul Şubesi için 10'ar katlı iki bina ve 30 katlı kuleler yapmak üzere E.R. Squibb \& Sons İlaç Fabrikası'nın arazisini 1987 yılında satın almıştır (Hürriyet, 2008) . Büyükdere Caddesi'nde fabrikaların hemen karşısındaki boş arazide Sabancı Holding ve Akbank gibi kuruluşların bulunduğu Sabancı Center inşa edilmiş ve 1993 yılında faaliyete geçmiştir. Bölgenin finans ve ticaret merkezi olma fonksiyonu İş Bankası Genel Müdürlüğü'nün 1996-2000 y1lları arasında yapımı tamamlanan İş Kulelerine taşınmasıyla daha belirgin hale gelmiştir. Bu yeni durum, mevcut fabrikaların farklı arayışlara girmesine neden olurken, Büyükdere Caddesi'ndeki sanayisizleşme sürecinin başlangıcını da oluşturmaktadır (Şekil 4).

Sanayisizleşme süreci uluslararası ticaret ve finans merkezi fonksiyonu üzerinden yaşanmaya başlarken, zaman içinde ticaret merkezi fonksiyonuna dönüşmüştür. Büyükdere Caddesi'nde (1. Levent - 4. Levent arası) 1952-1978 yılları arasında yer alan 13 sanayi tesisi, süreç sonrasında 6 plaza, 3 alışveriş merkezi içeren

5 1980'li yılların ikinci yarısında Levent ve çevresinde olușturulmak istenilen merkezi iş alanı, hızlı bir dönüşüme neden olmuştur. Buradaki fabrikalar kapanmaya ve yeni fonksiyona uygun yüksek katlı binaların yapımına başlanmıştır. Ancak bütün bu gelişmelere karşılık, 2000'li yıllardan itibaren siyasi irade Levent çevresinin değil, Anadolu yakasında finansman şirketlerinin yoğun olduğu bir uydu kentin kurulması yönünde tercihte bulunmuş ve Ataşehir'de İstanbul Finans Merkezi oluşturulmuştur. Halk Bankası'nın 2012 yılından itibaren İstanbul'da farklı lokasyonlarda bulunan birimlerini ve ardından da genel müdürlüğünü buraya taşımasından sonra, birçok finans ve sigorta kuruluşunun da şube veya temsilcilikleri ile bu alana geldiği görülmüştür. 


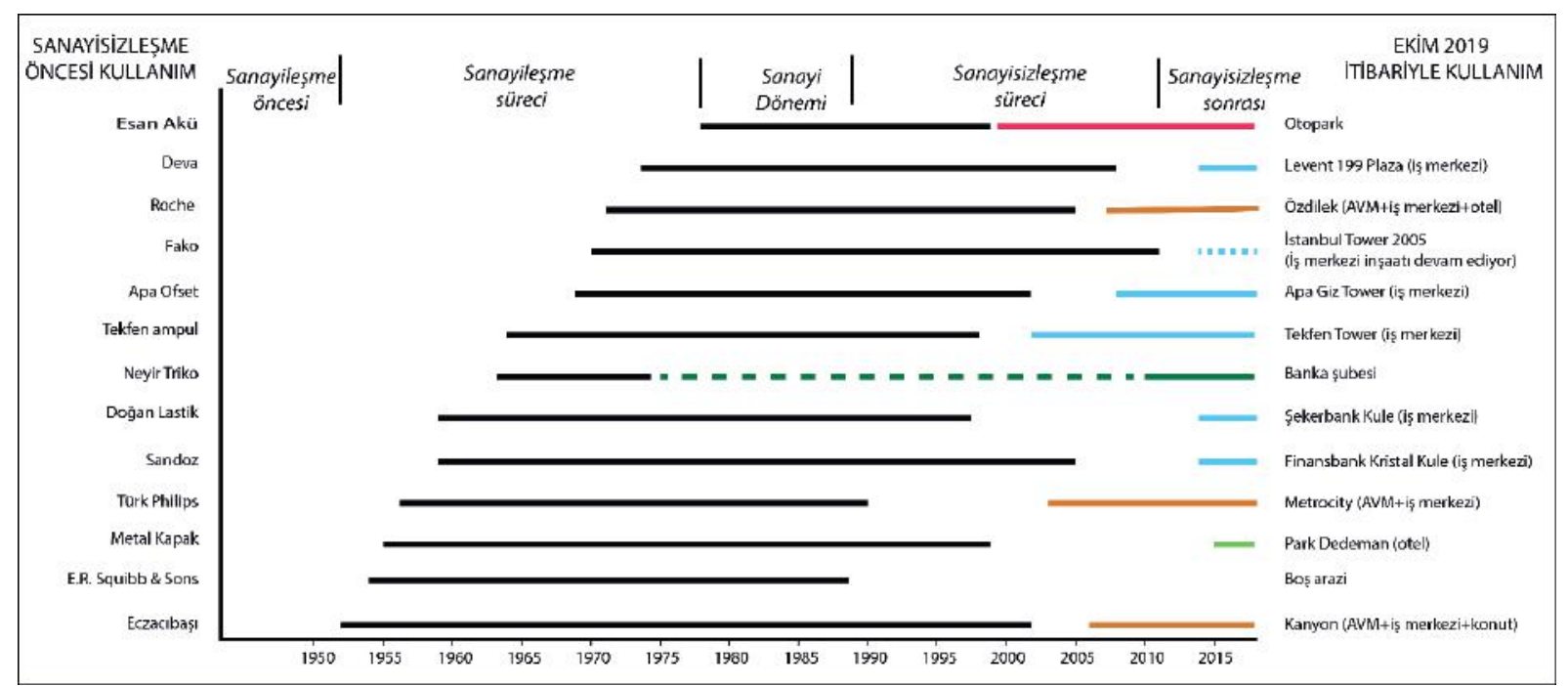

Şekil 4: Büyükdere Caddesinin (1. Levent-4. Levent arası) sanayileşme ve sanayisizleşme süreci.

Figure 4: Industrialization and deindustrialization of Büyükdere Street (between $1^{\text {st }}$ Levent- $4^{\text {th }}$ Levent).

yüksek konut ve işyeri ile bir otele dönüşmüş, bir fabrika binası da banka şubesi olarak kullanılmaya başlanmıştır. Fabrika alanlarından biri otopark haline getirilmiş, biri ise halen boş durmaktadır (Şekil 5). Fabrika alanlarının 10-15 yıl gibi kısa bir zaman diliminde fonksiyonel açıdan hızla dönüşmesindeki en önemli etken, mülkiyet durumlarıdır. Bu süreçte yatırımcılar, çok sayıdaki hissedarlar ile anlaşmanın gerekmediği, maliklerinin kurumsal muhataplardan oluştuğu bu gayrimenkuller üzerinde yeni yatırımlara karar verebilmiştir.

İlk sanayi tesislerinden Eczacıbaşı İlaç Fabrikası'nda üretimin bir kısmı 1982 yılında Ayazağa'ya taşınmış, 1992 yılından itibaren Lüleburgaz'daki tesis faaliyete geçmiştir. Fabrikada üretim 2002 yılına kadar devam etmiştir. Bu tarihte Eczacıbaşı Holding'in ilaç üreten iki firmasına ait hisselerin bir kısmı Zentiva N.V.'ye satılmış (bütün hisselerin devri 2009 yılında gerçekleşmiştir), ardından üretime son verilmiş̧ir. Günümüzde fabrika arazisinde 2003 yılında inşaatına başlanıp 2006 yılında açılan Kanyon Alışveriş Merkezi yer almaktadır. E.R. Squibb \& Sons İlaç Fabrikası'nda ise üretim 1980'li yılların ikinci yarısında durmuş, fabrika arazisinin 1987 yılında satılmasından sonra fabrika yıkılmıştır. 2012 yılı verilerine göre tahmini değeri 180 milyon dolar olarak belirlenen arsanın (Gökmen, 2012, s. 15) fonksiyonu, 2016 y1lında İstanbul Büyükşsehir Belediyesi tarafından imar planında yapılan bir değişiklik ile "dini tesis" alanına çevrilmiştir. 2016 yılındaki değerinin yaklaşık 250 milyon dolar civarında olduğu belirtilmektedir (Aksu, 2016). Gerekli yasal sürecin tamamlanmasından sonra Şubat 2020'de cami inşaatına başlanmıştır. İnşaatın 2 yıl sürmesi beklenmektedir.
Sandoz İlaç Fabrikası 1996 yılında Ciba-Geigy ile birleşmiş ve Novartis adı altında faaliyet göstermiş, 2005 yılında ise Kurtköy'deki (Pendik-İstanbul) tesislerine taşınmıştır. Fabrika arazisinde 2014 yılında yapımı tamamlanan Finansbank Kristal Kule isimli bina bulunmaktadır.

Philips televizyon fabrikası olarak bilinen binada, Türk Philips Sanayi adında bir kuruluş yer alıyordu. Tesiste 1957 yılından itibaren radyo, 1967 yllından itibaren de siyah beyaz televizyon üretimi gerçekleştirilmiştir. Tesiste 1982 yılında renkli televizyon üretimine geçilmiştir. Üretim faaliyetlerinin 1990 yılında Dudullu'daki fabrikaya taşınmasından sonra fabrika binası işlevsizleşirken, arazisi üzerinde 2003 yılında Metrocity Alışveriş Merkezi faaliyete geçmiştir.

1959 y1lında bisiklet ve motosiklet lastiklerinin üretildiği Doğan Lastik Fabrikası açılmıştır. Zaman içinde teknik kauçuk olarak tanımlanan elektrikli ev aletleri ve otomotiv sanayi gibi alanların ihtiyaç duyduğu ürünlerin üretildiği tesis, değişen koşullar nedeniyle bulunduğu yerde üretime devam edemediğinden 1990'lı yılların ikinci yarısında önce Ayazağa'ya, ardından da Gebze'ye taşınmıştır. Fabrika arazisi üzerinde Şekerbank Kule olarak bilinen işyerlerinin bulunduğu bina, 2014 yılında faaliyete geçmiştir.

Büyükdere Caddesi'nde 1960'lı y1llarda faaliyete geçen, ancak üretim fonksiyonunu erken dönemde yitiren tesislerden biri de Neyir Triko Fabrikası'dır. Neyir Triko önceleri Şişli' deki Bomonti sanayi bölgesinde yer alıyordu (Tümertekin, 1967, s. 66) Fabrika 1963-1964 yıllarında Büyükdere Caddesi’ne 


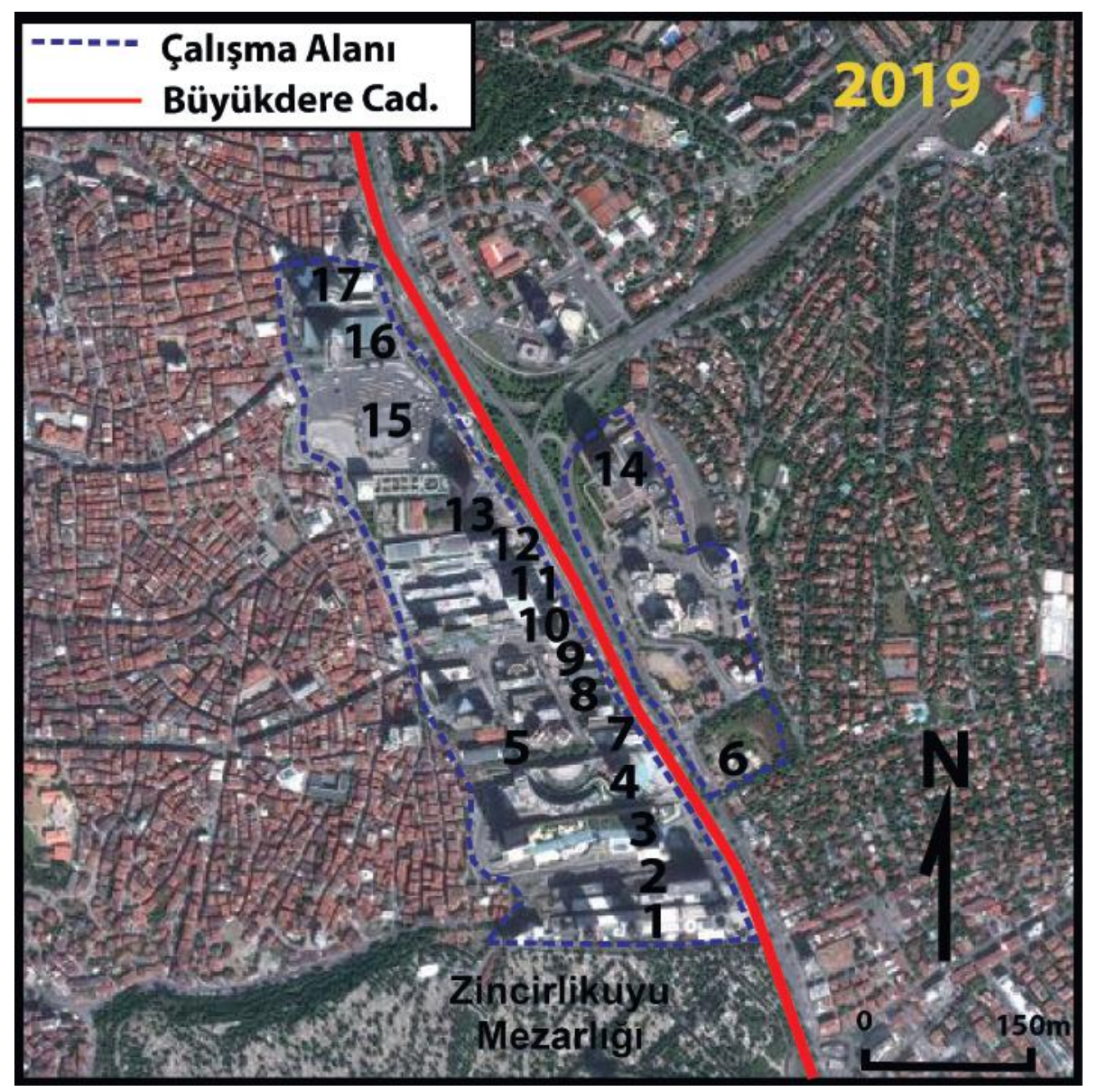

Şekil 5: Büyükdere Caddesinde (1. Levent-4. Levent arası) sanayisizleşme süreci sonrasında yeni kullanımlar [1-Metrocity AVM, 2-Signature Rezidans, 3-ÖzdilekPark AVM, 4-Kanyon AVM, 5-Polcenter AVM, 6-Cami inşaat alanı, 7-Dedeman Otel, Apa Giz Plaza, 9-Banka, 10-Levent199 Rezidans, 11-İstanbul Tower 205, 12-Tekfen Tower, 13-Yıldız Kule, 14-Kule Çarşı AVM, 15-iETT Otobüs Peronları, 16-Sapphire AVM, 17-Şekerbank Kulesi].

Figure 5: New uses after deindustrialization on Büyükdere Street (between $1^{\text {st }}$ Levent and $4^{\text {th }}$ Levent) [1-Metrocity Shoping Center, 2-Signature Residence, 3-ÖzdilekPark Shoping Center, 4-Kanyon Shoping Center, 5-Polcenter Shoping Center, 6-mosque construction area, 7-Dedeman Hotel, Apa Giz Plaza,

9-Bank, 10-Levent199 Residence, 11-Istanbul Tower 205 (residence), 12-Tekfen Tower, 13-Yıldız Kule, 14-Kule Çarşı Shoping Center, 15-Bus stops, 16-Sapphire Shoping Center, 17-Şekerbank Tower].

taşınmıştır. Binada tekstil üretimi 1974'e kadar sürmüştür Sahibinin ölümünden sonra üretimin sürdürülemediği, markanın satılmasını takiben üretimin başka yerde gerçekleştirildiği bilinmektedir. Bir dönem ofis olarak değerlendirilen bina, bir süre de adliye binası olarak kullanılmıştır. Günümüzde burada bir banka şubesi yer almaktadır.

1964 yılında bölgede faaliyete geçen bir tesis de Tekfen Ampul Fabrikasıdır. Tekfen özellikle inşaat ve taahhüt işleri yaparak gelişme göstermiştir. Şirketin web sayfasında "inşaat sektöründeki iş ve para akışının düzensizliğine karşı sanayi alanında yatırım yapmak amaciyla" İstanbul'da bir ampul fabrikasının kurulduğu bilgisi yer almaktadır. Fabrikada ampul ve aydınlatma konusu sadece ticari bir faaliyet olarak değerlendirilmemiş, aynı zamanda bir mühendislik ve kamusal eğitim konusu olarak düşünülerek fabrikanın giriş katında Tekfen Aydınlatma Enstitüsü kurulmuştur (Tekfen, 2019). 1998 yılında üretimin bir kısmı Gebze'ye aktarılmış, ardından Türkiye'nin ampul üretimi için cazip bir pazar olma özelliğini yitirmesi nedeniyle üretimin Çin'de devam ettirilmesine karar verilmiş̧ir. Fabrikanın arazisi üzerinde 2002 yılında faaliyete geçen Tekfen Tower yer almaktadır. Sanayisizleşmede sermayenin uluslararası hareketliliğine örnek olması açısından bu fabrikanın ayrı bir yeri vardır.

Levent sanayi alanında 1955 yılında faaliyete geçen fabrikalardan biri de Metal Kapak Kolektif Şirketi'ne ait Metal Kapak Fabrikası'dır. Metal sanayiine ait bu tesiste üretilen ürünler farklı sektörler tarafından kullanılmıştır. $\mathrm{Bu}$ tesiste yapılan kapakların üzerine ofset tekniği ile baskı da 
gerçekleştiriliyordu (Öner, 2014). Fabrikanın taşınmasından sonra arsasına yapılan Park Dedeman Otel 2015 yılında faaliyete geçmiştir. İstanbul'da matbaacılık uzun y1llar Cağaloğlu ve çevresinde yer almış, özellikle günlük gazeteler deniz yolu dışında Anadolu'ya ulaşmanın imkânsız olduğu dönemlerde bu alanı tercih etmişlerdir. Boğaziçi Köprüsü’nün (15 Temmuz Şehitler Köprüsü) yapımından sonra bir süre daha Cağaloğlu basın için merkez olmaya devam etmiş, daha sonra gazeteler farklı alanlara taşınmaya başlamışlardır. Günümüzde de yayınevleri açısından önde gelen merkezlerden olan Cağaloğlu'ndaki reklam ve yayın konusundaki tesislerden bir kısmı zaman içinde bölgeden ayrılmıştır. Türkiye'nin ilk ofset matbaası olan Apa Ofset 1969 yılından, 2000'li yılların başlarına kadar Büyükdere Caddesi'nde varlığını korumuş, fabrikanın Hadımköy’e taşınmasından sonra arazisinde Apa Giz Tower kurularak 2008 yılında faaliyete geçmiştir.

1970’li yıllarda Büyükdere Caddesi'nde 3 ilaç fabrikası ile 1 akü fabrikası kurulmuştur. 2005 yılında kapanan Roche İlaç Fabrikası'nın arazisinde Özdilek Alışveriş Merkezi, 2008 yılında kapanan Deva İlaç Fabrikası'nın arazisinde de Levent 199 Plaza 2014 yllında faaliyete geçmiştir. 2011 yılında üretimin tamamen sonlandığı Fako İlaç Fabrikası'nın arazisinde ise ofis ve konutların yer aldığı İstanbul Tower 205 yükselmektedir. Büyükdere Caddesi'nde incelenen alanın en kuzeyinde yer alan akü fabrikasının 1999 yılında bölgeden ayrılmasından sonra arazisi otopark olarak kullanılmaya başlanmıştır.

\section{SONUÇ}

Sanayisizleşme faaliyetlerinin farklı boyutlarının olduğu görülmektedir. Ekonomik açıdan ele alındığında sermaye, esas olarak daha uzun süre ve daha fazla gelir getirecek alanlarda yatırım yapmayı tercih etmektedir. Bunun sonucunda ülkeler ve/ veya bölgeler arasinda sermaye hareketleri söz konusu olmaktadır. (Ayik ve Avcı, 2018a, s. 1277). Sanayisizleşmenin mekânsal etkilerinden arazi kullanımı üzerine olanı, üretim faaliyetlerinin sona ermesinden sonra yeni kullanımların ortaya çıkması ile kendisini göstermektedir.

Sanayisizleşme, fonksiyonel açıdan ortaya çıkan değişimler yanında coğrafi görünümde de önemli değişikliklere işaret etmektedir. İstanbul ile ilgili bir çalışmada İstanbul'daki bazı sanayi tesislerinin kapanmasından sonra, sanayi alanlarındaki fonksiyonel değişim örneklerle ortaya konulmuştur (Ayik ve Avc1, 2018a; Ayik ve Avc1, 2018b). Sanayisizleşme sürecinin İstanbul'daki bir diğer yansıması, şehrin siluetinde neden olduğu değişikliklerdir. Büyükdere Caddesi'nin 1. Levent - 4. Levent arasinda kalan kesimi 2000'li yıllara kadar yüksekliği fazla olmayan 3-4 katlı fabrika binalarından meydana gelirken, günümüzde adeta gökyüzünü delen binaların oluşturduğu bir görünüm kazanmıştır (Fotoğraf 3 ve Fotoğraf 4).

Büyükdere Caddesi'ndeki tesisler, sanayisizleşmenin 3 farklı boyutuna da örnek oluşturmaktadır. Bu tesislerden bir kısmı şehirmerkezinden çepere doğruyer değişimine (desantralizasyon) örnek oluştururken, bazıları daha uygun koşulların olduğu yeni alanlara (relocation) taşınmıştır. Büyükdere Caddesi örneğinde Levent'ten Ayazağa veya Gebze'ye taşınan sanayi tesisleri daha çok merkezden çevreye doğru yayılmaya, Trakya'daki bazı sanayi odaklarına taşınan fabrikalar da (Deva İlaç, Eczacıbaşı İlaç gibi) daha uygun koşullu alanlara taşınmaya örnek oluşturmaktadır. Fako İlaç Fabrikası veya Tekfen Ampul Fabrikası örneğinde olduğu gibi hem ekonomik, hem de mekânsal olarak sanayisizleşmeye (deindustrialization) örnek oluşturan fabrikalar da mevcuttur.

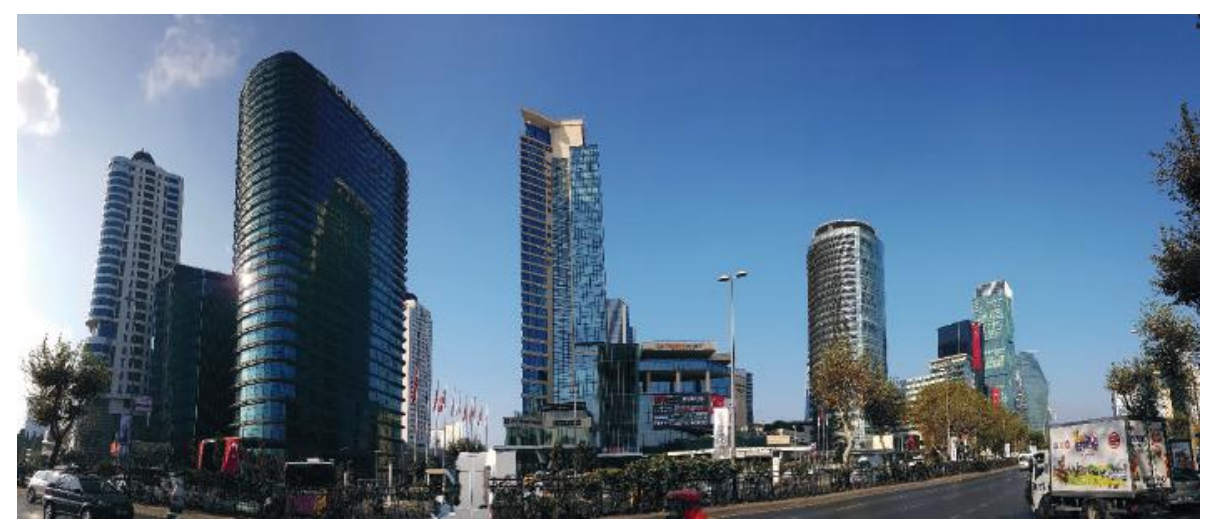

Fotoğraf 3: Büyükdere caddesinde (1. Levent-4. Levent arası) eski fabrikaların olduğu alanda yer alan AVM, Rezidans ve bürolar (29 Ekim 2019).

Photo 3: Shopping centers, residences and offices located in the area of the old factories on Büyükdere Street (between $1^{\text {st }}$ Levent and $4^{\text {th }}$ Levent)

(October 29, 2019). 


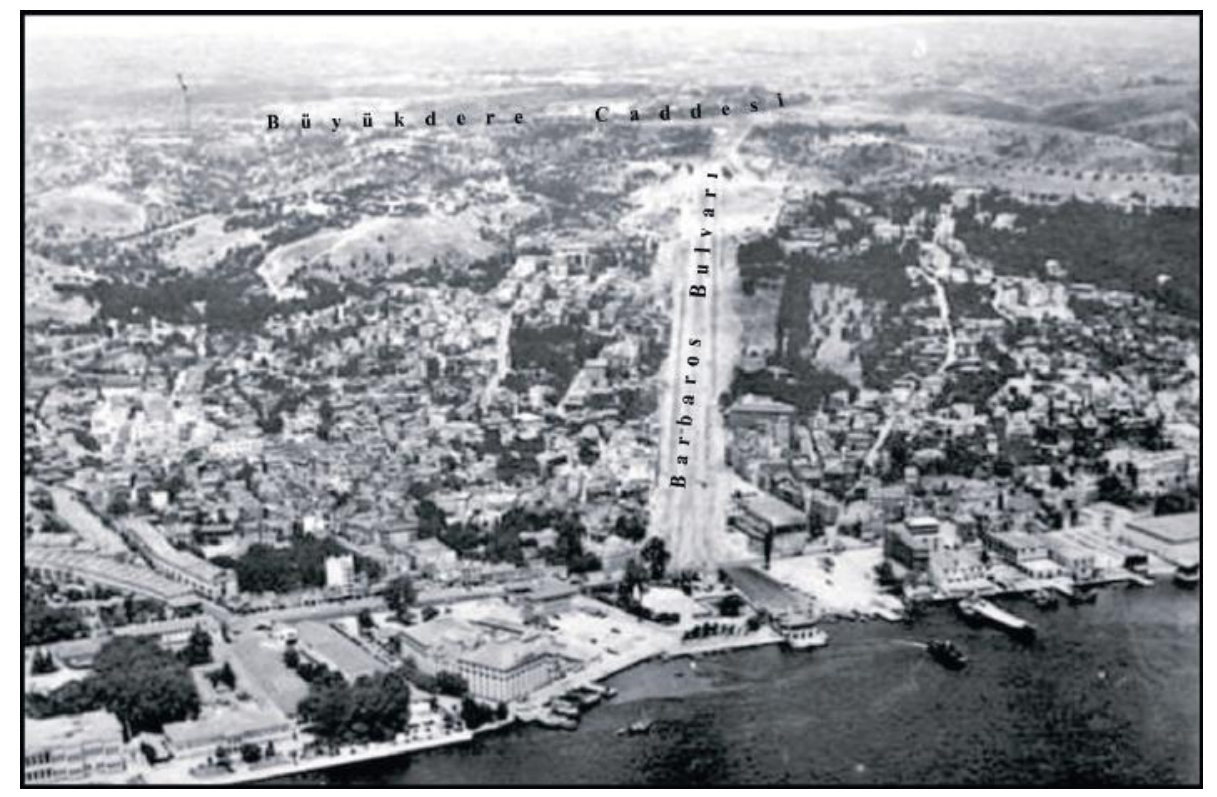

Fotoğraf 4: 1958 yılında çekilen bir fotoğrafta yeni açılan Barbaros bulvarının inşaatı ve geride plato düzlüğü üzerinde yer alan Büyükdere caddesi (Beşiktaş Belediyesi).

Photo 4: In a photograph taken in 1958, the construction of the newly opened Barbaros boulevard and Büyükdere street on the plateau plain (Beşiktaş Municipality).

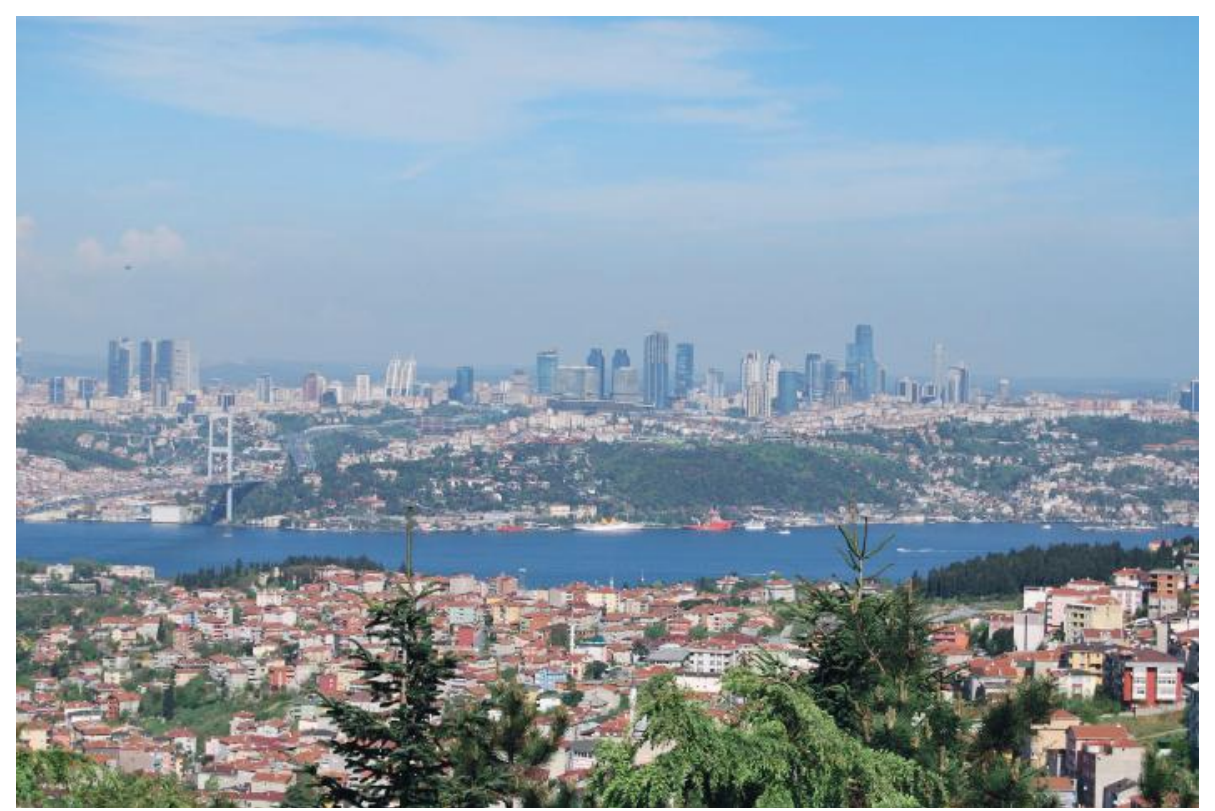

Fotoğraf 5: İstanbul'un Avrupa yakasının ufuk çizgisine gökdelenler damgasını vurur. Photo 5: The skyline of Istanbul's European side is marked by skyscrapers.

1980'li yıllarda dünyada yaşanan ekonomik sorunlar, sosyal liberal (Keynesyen) ekonomi politikalarından vazgeçilerek, neoliberal ekonomi politikalarının uygulanması ile aşılmaya çalışılmıştır. Küreselleşme, bu dönemin anahtar kelimesidir. Şehirlerin dönüşümünde bir evre de, küreselleşme ile yaşanmaya başlamıştır. 1970'li yıllardan itibaren batıdaki sanayi şehirlerinde yaşanan çöküntünün bir sonucu olarak üretim mekânlarının tüketim mekânlarına dönüştüğü, küresel ekonomi için hizmet sektörünün ön plana çıktı̆̆ belirtilmektedir (Urry, 1995'e atfen Türkün ve Kurtuluş, 2016: 13). İstanbul'un sanayisizleşmesi de yaşanan dönüşümlerin bir sonucu olarak karşımıza çıkmaktadır.

İstanbul'un sanayi tesislerinin kuruluş yeri olarak belirlenmesinde, ulaşım açısından taşıdığı önem ve pazar 
büyüklügü, nitelikli ve niteliksiz her türlü bol iş gücü imkânı gibi unsurlar, sermaye için tercih edilen bir yer olmasını sağlamıştır. Ancak İstanbul içinde sanayi alanlarının yer seçimi, bazen planlı, çoğu zaman da plansız olarak gerçekleşmiştir. Tümertekin, 1966 yılı Sanayi Planı'nda toplamda 1140,5 hektar olan sanayi alanının 1980 Nazım Planı'nda 5959,5 hektara çıkmasını, planda yer verilmeyen alanların sanayi alanlarına katılmasının bir sonucu olduğunu belirtmektedir (Tümertekin, 1997, s. 16). Çoğu zaman ortaya çıkan fiili durumun planlanmaya çalışılması, İstanbul ile ilgili yapılan planların durumunu açıklayan güzel bir ifadedir. Sanayi tesislerinde üretimden elde edilecek kârın başka mekânlarda da elde edilebileceği gerçeği, alana farklı fonksiyonlar yüklenebilmesine zemin hazırlamıştır. Yukarıda da belirtildiği gibi 1990'lardan itibaren söz konusu alana, uluslararası ticaret ve finans merkezi olma fonksiyonu kazandırılmaya çalışılmıştır. Böylece sanayide üretim ile kazanılandan çok daha fazlasını kazanmak mümkün olabilecektir. Sanayi alanı olarak belirlenmesinde nispeten kısa bir süre sonra Büyükdere Caddesi'nin 1. Levent - 4. Levent arasındaki kesiminin sanayiden arındırılmasında en büyük etkenin rant olduğu, süreçten de anlaşılmaktadır. Alanın "uluslararası iş ve finans merkezi" fonksiyon sahası olarak gelişmesinde İş Bankası, Akbank ve Sabancı Holding'in idari merkezlerinin bu alana taşınması da yeterli olmamıştır. Planlarda yapılan değişiklikler ile fabrika alanları, öncelikle şirketler için büroların yer aldığ yüksek binalara dönüşmüştür. Ancak talepten hızlı gerçekleşen arz, binaların bir kısmının boş kalmasına neden olduğu için yeni projelerde binalar içinde konut alanları, bazı binalarda ise alışveriş merkezleri yer almaktadır. Bu fonksiyon değişiminden beklenen kârın sadece maddi olması da gerekmemektedir. Bunun bir örneğini E.R. Squibb \& Sons İlaç Fabrikası arazisinde görmek mümkündür. Yapılan imar planı değişiklikleri ile bu saha içinde bir caminin yer alacağı dini yapı fonksiyonu belirlenmiştir.

Şehirlerin gelişimi, coğrafi görünümde önemli değişikliklere neden olmaktadır. Büyükdere caddesinde sanayileşme süreci, arazi kullanımında büyük bir değişiklik yaratmış tarım yapılan veya boş durun alanlar sanayi alanına dönüşmüş̧ür. Buna karşılık, sanayisizleşme süreci arazi kullanımında fonksiyonel değişikliklere neden olmanın yanında, şehrin siluetinin farklılaşmasına da yol açmıştır.

Teşekkür: Bu makale, İstanbul Üniversitesi Sosyal Bilimler Enstitüsü Coğrafya Doktora Programı'nda Prof. Dr. Sedat Avcı danışmanlığında Uğurcan Ayik tarafından tamamlanan "Ekonomi Politikalarının Bir Yansıması olarak Sanayisizleşme ve Mekânsal Değişim: Istanbul Örneğ i" başlıklı doktora tezinin arazi çalışmaları sırasında elde edilen verilerden bir kısmının detaylı olarak değerlendirilmesiyle, tezden bağımsız olarak hazırlanmıştır. Yazarlar, yapıcı eleştirilerinden dolayı hakemlere, çalışmanın şekillenmesinde önemli katkıları olan sanayi tesislerinin çeşitli kademelerindeki çalışanlarına ve geçmiş günlere ait hatıralarını paylaşan Gültepe sakinlerine teşekkür ederler.

Hakem Değerlendirmesi: Dış bağımsız.

Çıkar Çatışması: Yazarlar çıkar çatışması bildirmemiştir.

Finansal Destek: Yazarlar bu çalışma için finansal destek almadığını beyan etmiştir.

Acknowledgement: This article has been prepared independently from the thesis by evaluating some of the data obtained during field studies of the $\mathrm{PhD}$ thesis titled "Deindustrialization and spatial change as a implication of economic policies: Istanbul example". The authors would like to thank the referees for their constructive criticism, the employees at various levels of the factories that have contributed significantly to the shaping of the work, and the residents of Gültepe who shared their memories of the past.

Peer-review: Externally peer-reviewed.

Conflict of Interest: The authors have no conflict of interest to declare.

Grant Support: The authors declared that this study has received no financial support.

\section{KAYNAKÇA/REFERENCES}

Akbayar, N. (1998). Yönetsel yapının tarihsel gelişimi. N. Akbayar (Dü.) içinde, Dünden Bugüne Beşiktaş (s. 47-50). İstanbul: Beşiktaş Belediye Başkanlığı.

Aksu, F. (2016, 01 26). Merkez Bankası arsasının planı değiştirildi. 03 04, 2019 tarihinde Hürriyet Ekonomi: http://www.hurriyet.com.tr/ ekonomi/merkez-bankasinin-arsasinin-plani-degistirildi-40045502 adresinden alınd.

Aoyama, Y., Murphy, J. T., \& Hanson, S. (2011). Key Concept in Economic Geography. London: Sage Publications Ltd.

Artan, T. (1994). Tarihte Boğaziçi. Dünden Bugüne İstanbul Ansiklopedisi, 2, 281-286. İstanbul: Türkiye Ekonomik ve Toplumsal Tarih Vakfi.

Avcı, S. (2014). Mekânsal planlama, mekâna müdahale ve sonuçları açısından 2b alanları: Beykoz ilçesi örneği. Ü. Akkemik (Dü.) içinde, İstanbul Ormanlarının Sorunları ve Çözüm Önerileri (s. 313-340). İstanbul: Türkiye Ormancılar Derneği Marmara Şubesi.

Ayik, U. (2018). Ekonomi politikalarının bir yansıması olarak sanayisizleşme ve mekânsal değişim: İstanbul Örneği. İstanbul: İstanbul Üniversitesi Sosyal Bilimler Enstitüsü (Basılmamış Doktora Tezi).

Ayik, U., \& Avc1, S. (2018a). Ekonomik ve mekânsal boyutlarıyla sanayisizleşme. TÜCAUM 30. Yll Uluslararası Coğrafya Seтроzуити 3-6 Ekim 2018 (s. 1276-1288). Ankara: Ankara Üniversitesi Türkiye Coğrafyası Araştırma ve Uygulama Merkezi.

Ayik, U., \& Avc1, S. (2018b). İstanbul'da sanayizleşme. Asos Journal Akademik Sosyal Araştırmalar Dergisi (65), 505-523.

Aysu, Ç. (1994). Büyükdere caddesi. Dünden Bugüne İstanbul Ansiklopedisi, 2, 361-363. İstanbul: Türkiye Ekonomik ve Toplumsal Tarih Vakfi.

Aysu, Ç. (2006). Boğaziçi’nde yoğun şehirleşme alanları: Bazı Örnekler. N. Özgüç, \& A. Timor (Dü) içinde, Insan ve Mekân (Prof. Dr. Erol Tümertekin'e Armağan (s. 105-128). İstanbul: Çantay Kitabevi.

Baydar, O. (1998). Levent. N. Akbayar (Dü.) içinde, Dünden Bugüne Beşiktaş (s. 47-50). İstanbul: Beşiktaş Belediye Başkanlığı.

Erbaş, A. (2012). Örnek bir prestij konut alanı olarak Levent Mahallesi. Tasarım+Kuram(8), 5-7. 
Frank, A. G. (1967). Capitalism and Underdevelopment in Latin America. New York: Montly Review Press.

Gökmen, L. (2012, Nisan 22-28). İstanbul'un altın değerinde arazileri. Ekonomist, s. 14-17.

Görcelioğlu, E. (1985). Belgrad ormanlarındaki tarihi bentler. Ístanbul Üniversitesi Orman Fakültesi Dergisi, Seri B, 35(3), 47-59.

Haggett, P. (1965). Locational Analysis in Human Geography. Great Britain: Edward Arnold.

Harvey, D. (2007). A Brief History of Neoliberalism. New York: Oxford University Press Inc.

Hürriyet. (2008). Levent'teki arsa ağzı sulandırıyor, Ataşehir 'Altınşehir' oluyor. 23.05.2020 tarihinde https:/www.hurriyet.com.tr/gundem/ leventteki-arsa-agiz-sulandiriyor-atasehir-altinsehir-oluyor-8038 882 adresinden alınd.

İşli, N. (1991). Asri mezarlık. İslam Ansiklopedisi, 3, 503. İstanbul: Türkiye Diyanet Vakfi.

Kağıthane. (2008). Kă̆ıthane Rehberi. İstanbul: Kağıthane Belediyesi.

Krugman, P. (1980). Scale economies, product differentiation, and the pattern of trade. The American Economic Review, 70(5), 950-959.

Krugman, P. (1991). Increasing returns and economic geography. Journal of Political Economy, 99(3), 483-499.

Launhardt, W. (1882). Die bestimmung des zweckmassigsten standorts einer gewerblichen anlage. Zeitschrift des Vereins Deutscher Ingenieure, 106-115.

Lösch, A. (1978). The Economics of Location. (W. H. Woglom, Çev.) New Haven ve London: Yale University Press.

Olivier, A. (2016). 18. Yüzyılda İstanbul ve Türkiye. (A. Kaplan, Çev.) İstanbul: Köprü Kitapları.
Öktem, B. (2016). Küresel kent söyleminin kentsel mekânı dönüştürmedeki rolü (Büyükdere-Maslak Aksı). H. Kurtuluş (Dü.) içinde, Ístanbul'da Kentsel Ayrışma - Mekânsal Dönüşümde Farklı Boyutlar (s. 25-76). İstanbul: Bağlam Yayınları.

Öner, A. E. (2014). Ustadan Çırağa Bir Gelenek-Türk Teneke Ambalaj Sanayi Tarihi. İstanbul: Kurumsal Yayınlar.

Tapan, M. (1998). İstanbul'un kentsel planlanmasının tarihsel gelişimi ve planlama eylemleri. Y. Sey (Dü.) içinde, 75 Yılda Değişen Kent ve Mimarlık (s. 75-88). İstanbul: Türkiye Ekonomik ve Toplmusal Tarih Vakfi.

Tekfen. (2019). Tarihçe. 13.10.2019 tarihinde Tekfen Holding: http:// www.tekfen.com.tr/tarihce.asp adresinden alındı

Tümertekin, E. (1967). İstanbul'da Bir Sanayi Bölgesi: Bomonti - Bir Tatbiki Coğrafya Çalışması. İstanbul: İstanbul Üniversitesi.

Tümertekin, E. (1970). İstanbul şehri ve çevresine sanayi: Özellikler ve dağılış. İstanbul Üniversitesi Coğrafya Enstitüsü Dergisi (17), 3367.

Tümertekin, E. (1972). İstanbul Sanayiinde Kuruluş Yeri. İstanbul: İstanbul Üniversitesi Coğrafya Enstitüsü.

Tümertekin, E. (1997). İstanbul İnsan ve Mekân. İstanbul: Tarih Vakfi Yurt Yayınları.

Türkün, A. \& Kurtuluş, H. (2016). Giriş. H. Kurtuluş (Dü.) içinde, Ístanbul'da Kentsel Ayrışma (s. 9-24). İstanbul: Bağlam Yayıncılık. Urry, J. (1995). Consuming Places. London: Routledge.

Wallerstein, I. (1979). The Capitalist World-economy. Cambridge: Cambridge University Press.

Weber, A. (1929). Theory of the Location of Industries. (C. J. Friedrich, Çev.) Chicago: University of Chicago Press. 
